\title{
Editorial
}

\section{Peter Merriman}

Transdisciplinary exchanges and interdisciplinary debates have always lain at the heart of Transfers, but such movements generate challenges and unanswered questions as well as productive tensions. Has a new amorphous multidisciplinary field called "mobility studies" emerged, or do disciplinary debates and imperatives still underscore mobilities scholarship? How do "mobility studies," "transport studies," "mobility history," "transport history," "media history," "migration studies," and other fields intersect, differ, or interact with one another? Do the variations among different strands of mobilities research reflect distinct differences in method, approach, and style in the social sciences, arts, and humanities, or do they generate interesting questions that cross disciplines? How are different journals-Transfers, Mobilities, The Journal of Transport History, and Applied Mobilities-(re)positioning themselves, and what makes them distinct and different? Should we stop forming camps or drawing boundaries around subdisciplines, and stop asking questions like those framed above? There are no easy or correct answers to any of these questions, but I would suggest that Transfers occupies a privileged position at the intersection of the humanities, arts, and social sciences. This position can enable the journal to serve as an important "melting pot" (or "salad bowl") wherein artistic experiments, findings from archival research, social theories, and discussions of mobility policy can sit more or less comfortably alongside one another, and can even be melded together in specific studies.

Transfers, then, is pivotal in ongoing moves to "frame" mobility studies not simply as a pursuit of the social sciences ${ }^{1}$ but also as a key concern of scholars and practitioners working across the arts and humanities, whether in history, cultural and historical geography, literary and cultural studies, performance studies, archaeology, philosophy, film studies, or art and design. ${ }^{2}$ Since its launch, Transfers has positioned artistic and curatorial practices as key areas of concern; has published reviews of films, exhibitions, and museums with a mobility focus; and has featured visual essays by artists for whom mobility is a central subject, object, method, or technique of their practices. Movement, then, has become a key concern of artists working in different media, as evidenced by the "Mobility and Art" section of Transfers and in publications linked to projects such as Stop and Go (funded by the Vienna Science and Technology Fund), ${ }^{3}$ Slices of (Mobile) Life (funded by the EU and Mobile Lives Forum $){ }^{4}$ and the Mobile Utopia: Art and Experiments exhibition at the 2017 joint $\mathrm{T}^{2} \mathrm{M}$ (International Association for the History of Transport, Traffic and 
Mobility) and Cosmobilities Network conference in Lancaster, United Kingdom. ${ }^{5}$ The launch of an inaugural UK symposium for the Art and Mobilities Network in July 2018 promises to bring together a diverse array of participants concerned with exploring different theories, methods, practices, aesthetic techniques, and political implications surrounding artistic approaches to mobility. In examining the intersection of mobility and aesthetics, arts and humanities scholars might find it useful to rework the concept of kinaesthetics from dance theory and sensory studies, something that Lynne Pearce and I suggested in a recent edited collection on Mobility and the Humanities. ${ }^{6}$ Whereas the concept of kinaesthesis refers to "the sense of muscular effort that accompanies a voluntary motion of the body,"7 the term "kinaesthetics" can be refashioned in order to highlight the aesthetic dimensions of movement as it is "enacted, felt, perceived, expressed, metered, choreographed, appreciated and desired" by embodied subjects of different kinds. ${ }^{8}$ Mobility aesthetics, then, would not just be concerned with the production, generation, or interpretation of representations of mobility. Rather, it could be seen to encompass all manner of creative processes, practices, and embodied movements that generate aesthetic affects and effects and are apprehended by embodied subjects in different ways. Reworked this way, kinaesthetics may serve as an important concept through which to understand interdisciplinary themes of embodied movement, artistic practices, subject formation, and politics. Transfers will, I hope, play an important role in facilitating the publication of future academic research and artistic practice on the aesthetics of mobility, or kinaesthetics.

Peter Merriman is an Associate Editor of Transfers and Professor of Human Geography in the Department of Geography and Earth Sciences at Aberystwyth University, Wales. He is the author or editor of six books, including Mobility and the Humanities (2018), coedited with Lynne Pearce.

E-mail:prm@aber.ac.uk

\section{Notes}

1. See Mimi Sheller and John Urry, “The New Mobilities Paradigm," Environment \& Planning A 38, no. 2 (2006): 207-226; Mimi Sheller and John Urry, "Mobilizing the New Mobilities Paradigm," Applied Mobilities 1, no. 1 (2016): 10-25.

2. See Peter Merriman and Lynne Pearce, "Mobility and the Humanities," Mobilities 12, no. 4 (2017): 493-508; Susanne Witzgall, Gerlinde Vogl, and Sven Kesselring, eds., New Mobilities Regimes in Art and Social Sciences (Farnham, UK: Ashgate, 2013). 
3. See Michael Hieslmair and Michael Zinganel, Road* Registers: Logbook of Mobile Worlds (Vienna: Tracing Spaces, Institute for Artistic and Scientific Research, 2016).

4. Emmanuel Ravalet, Stéphanie Vincent-Geslin, Vinvent Kaufmann, and Jean Leveugle, Slices of (Mobile) Life: A Sociological Study and Manifesto on WorkRelated High Mobility (Paris: Éditions Loco-L'Atelier d'édition and Mobile Lives Forum, 2014).

5. Jen Southern, Emma Rose, and Linda O'Keeffe, Mobile Utopia: Art and Experiments. An Exhibition (Lancaster, UK: CeMoRe, Lancaster University, 2017).

6. Peter Merriman and Lynne Pearce, eds., Mobility and the Humanities (London: Routledge, 2018).

7. OED Online, s.v. "kinaesthesis," http://www.oed.com/view/Entry/103437?redir ectedFrom=kinaesthetic (accessed 16 March 2018).

8. Merriman and Pearce, "Mobility and the Humanities," 498. 
This page intentionally left blank 